\title{
Body image satisfaction, sociodemographic, functional and clinical aspects of community-dwelling older adults
}

\author{
Raquel Rousselet Farias ${ }^{1}$, Renata Breda Martins², Vivian Ulrich³ ${ }^{3}$ João Henrique Correa Kanan4, \\ Irenio Gomes da Silva Filho ${ }^{5}$, Thais de Lima Resende ${ }^{6}$
}

\begin{abstract}
Body image, according to the definition by Ledoux et al. ${ }^{1}$ is "the systematic, cognitive, affective, conscious, and unconscious representation that people have concerning their bodies during their biological development and throughout their social relationships". Objective: To determine the prevalence of body image satisfaction (BIS) and its relationship with sociodemographic, functional and clinical aspects in older adults. Methods: A cross-sectional, analytical and prospective study of a random sample of older adults from all health districts of Porto Alegre (30 health units) was conducted. The following aspects were studied: sociodemographic data (sex, age, marital status and education), BIS (Stunkard's scale), functional tests (30 seconds Sit/Stand Test, time to walk 10m, Handgrip Strength - HGS), physical activity (Minnesota Questionnaire) and cognition (Mini-Mental State Examination). Results: Most of the 532 participants were dissatisfied with their body image (92.5\%), particularly the women (71.7\%). After Binary Logistic Regression (6 steps), BIS predictors were: high scores for the Sit/Stand (OR: 1.13; $p=0.013$ ), higher HGS (OR: 1.06; $p=0.049$ ), shorter time engaged in physical activity (OR: $0.77 ; p<0.001)$. Conclusion: The prevalence of BIS was low and most of the variables analyzed bore no relation to BIS. Notwithstanding, a relationship was found with greater HGS, higher Sit/Stand score and less time engaged in physical activity. Given the scarcity of studies on this subject, our study furthers the knowledge on how body image affects this population group.
\end{abstract}

Key words: aged, aging, body image, primary health care, public health.

SATISFAÇÃO DA IMAGEM CORPORAL, ASPECTOS SOCIODEMOGRÁFICOS, FUNCIONAIS E CLÍNICOS DE ADULTOS COMUNITÁRIOS

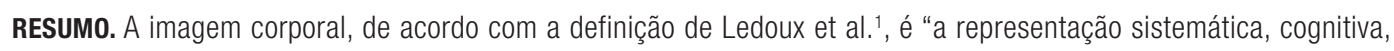
afetiva, consciente e inconsciente que as pessoas possuem em relação ao seu corpo durante 0 seu desenvolvimento biológico e ao longo de suas relações sociais". Objetivo: Determinar a prevalência de satisfação com a imagem corporal (BIS) e sua relação com aspectos sociodemográficos, funcionais e clínicos em idosos. Métodos: Estudo transversal, analítico e prospectivo, realizado em uma amostra aleatória de idosos de todos os distritos sanitários de Porto Alegre (30 unidades de saúde). Os seguintes aspectos foram estudados: dados sociodemográficos (sexo, idade, estado civil e escolaridade), BIS (escala de Stunkard), testes funcionais (30 segundos Sit/Stand Test, tempo de caminhada 10m, Handgrip Strength - HGS) atividade física (Minnesota Questionnaire) e cognição (Mini Mental State Examination). Resultados: A maioria dos 532 participantes estava insatisfeita com a imagem corporal $(92,5 \%)$, particularmente as mulheres $(71,7 \%)$. Após a Regressão Logística Binária (6 passos), os preditores do BIS foram: escores altos para 0 sentar/levantar (OR: 1,13; $p=0,013$ ), maior FP (OR: 1,06; $p=0,049$ ), menor tempo gasto em atividade física (OR: 0,77; $p<0,001)$. Conclusão: A prevalência do BIS foi baixa e a maioria das variáveis analisadas não apresentou relação com

\footnotetext{
This study was conducted at the Institute of Geriatrics and Gerontology, Pontifical Catholic University of Rio Grande do Sul, Porto Alegre, RS, Brazil.
}

${ }^{1}$ Specialist. School of Health Sciences, Pontifical Catholic University of Rio Grande do Sul, Porto Alegre, RS, Brazil. "2Specialist. School of Health Sciences, Pontifical Catholic University of Rio Grande do Sul, Porto Alegre, RS, Brazil. ${ }^{3}$ Specialist. School of Health Sciences, Pontifical Catholic University of Rio Grande do Sul, Porto Alegre, RS, Brazil. ${ }^{4}$ PhD. Department of Microbiology, Immunology and Parasitology, Federal University of Rio Grande do Sul, Porto Alegre, RS, Brazil. ${ }^{5}$ PhD. Institute of Geriatrics and Gerontology Pontifical Catholic University of Rio Grande do Sul, Porto Alegre, RS, Brazil. ${ }^{6}$ PhD. School of Health Sciences, Pontifical Catholic University of Rio Grande do Sul, Porto Alegre, RS, Brazil.

Thais de Lima Resende. PUCRS / Escola de Ciências da Saúde - Av. Ipiranga, 6690 / Prédio 81 / $6^{\circ}$ andar / sala 603 - $90619-900$ Porto Alegre RS - Brazil. E-mail: thaislr@pucrs.br

Disclosure: The authors report no conflicts of interest.

Received April 05, 2018. Accepted in final form June 25, 2018

(c) BY 
o BIS. Não obstante, foi encontrada uma relação com maior FPP, maior escore de Sit/Stand e menor tempo gasto em atividade física. Devido à escassez de estudos sobre o assunto, nossa pesquisa ajuda a aumentar o conhecimento sobre como a imagem corporal afeta essa parcela da população.

Palavras-chave: idoso, envelhecimento, imagem corporal, atenção primária à saúde, saúde pública.

$\mathrm{B}_{\mathrm{a}}^{\mathrm{od}}$ dy image, according to the definition by Ledoux et al. ${ }^{1}$ is "the systematic, cognitive, affective, conscious, and unconscious representation that people have concerning their bodies during their biological development and throughout their social relationships". It is still scarcely reported in the literature and most studies evaluate adolescents and adults. ${ }^{2-4}$ The investigations with younger populations point to the predominance of body image dissatisfaction among women ${ }^{3,5}$ and its association with the risk of developing chronic diseases, ${ }^{6}$ difficulty in changing habits that are harmful to health, ${ }^{7}$ besides worse quality of life, physical and mental health. ${ }^{8}$

The paucity of studies on body image satisfaction (BIS) is most evident regarding studies with older adult populations and its relationship with other characteristics inherent to the aging process. ${ }^{2,9}$ As is the case in younger individuals, when body image is analyzed in older adults dissatisfaction is frequent., ${ }^{3,-14}$ However, in spite of the higher prevalence of body image dissatisfaction, there are indications that the greatest concern in this age group is physical ability/competence, ${ }^{2,9,15}$ while BIS is positively associated with perceived good health, ${ }^{15}$ quality of life and well-being. . $^{15,16}$

Inexorable, physiological aging promotes significant losses in the various systems of the human body which, when associated with pathological and/or degenerative processes, can exacerbate them and lead to physical dependence and loss of autonomy. ${ }^{17}$ Thus, within the global and national situation of a rapidly aging population, ${ }^{18}$ as well as the impact this has on health systems, ${ }^{17}$ it is relevant to study this construct in terms of health and quality of life. Moreover, users of public primary care units in Brazil have greater social, environmental and health vulnerability, ${ }^{19}$ which is even greater among the aged population. The objective of the present study, therefore, was to determine the prevalence of BIS and its relationship with sociodemographic, functional and clinical aspects of older public Primary Care users from Porto Alegre, Rio Grande do Sul state, Brazil.

\section{METHODS}

This cross-sectional analytical study was conducted from March 2011 to December 2012 with the approval of the Research Ethics Committee of the Pontifical Catholic University of Rio Grande do Sul - PUCRS (protocol number 10/04967) and the City Health Department of Porto Alegre/RS (001.021434.10.7), ${ }^{20}$ fully complying with the Declaration of Helsinki. Written informed consent forms were signed by each participant or carer. A detailed description of all methods adopted for the present study can be found in Gomes et al. ${ }^{20}$

The study involved a random sample of 587 older adults from 30 different public Primary Health Care units (Family Health Strategy units) in Porto Alegre, representative of all the city's health districts. This particular set of health units - Family Health Strategy are usually established in areas that have greater social, environmental and health vulnerability. ${ }^{19}$

The study was run in two phases: [1] General data collection carried out at subjects' homes, where an instrument was used to collect sociodemographic and economic data (Older Adult Global Assessment Questionnaire), as well as reported morbidity and behaviors that interfere with health; [2] Specialized evaluations carried out at the São Lucas Hospital of the PUCRS by a multidisciplinary team assessing the clinical, nutritional and physical aspects of the older adults. ${ }^{20}$

The study included people aged 60 years and over, who were registered users of the 30 randomly selected health units. Those who were unable to travel to the outpatient clinics of the São Lucas Hospital for the multiprofessional evaluation using the transportation offered by the research group were excluded..$^{20}$

For the present study, the following variables were used: gender, age, age group, marital status, education, BIS (Stunkard's Scale), ${ }^{21}$ the 30s Sit/Stand test, ${ }^{22}$ handgrip strength (HGS), ${ }^{23}$ time (seconds) to walk 10 meters, ${ }^{24}$ the number of minutes per week engaged in light, moderate and intense physical activity, ${ }^{25,26}$ the presence or absence of cognitive decline (Mini-Mental State Examination), ${ }^{27}$ urinary incontinence, reported falls in past year, number of falls in past year, fracture due to falls, use of medication, and polypharmacy. The description of the variables, the instruments used, and the place of data collection are shown in detail in Table 1.

Data were analyzed using the Statistical Package for Social Sciences version 20.0 (SPSS Inc., Chicago, IL). A $5 \%$ significance level was used for statistical decisions. The data distribution study was performed using the Kolmogorov-Smirnov test. 
Table 1. Description of study variables, instruments used and place of data collection.

\begin{tabular}{|c|c|c|c|c|}
\hline \multirow[b]{2}{*}{ Variable type } & \multirow[b]{2}{*}{ Variable } & \multirow[b]{2}{*}{ Categories } & \multicolumn{2}{|l|}{ Data collection } \\
\hline & & & Instrument & Place \\
\hline \multirow[t]{4}{*}{ Sociodemographic } & Age & None & OAGAQ* & Home \\
\hline & Age group & $60-69 ; 70-79 ; \geq 80$ years & OAGAQ* & Home \\
\hline & Education & Illiterate; low; medium; high education & $O A G A Q^{\star}$ & Home \\
\hline & Marital status & Living with a partner/not living with a partner & OAGAQ* & Home \\
\hline \multirow[t]{4}{*}{ Functional } & Time (s) to walk $10 \mathrm{~m}$ & None & Chronometer & $\mathrm{SLH}^{+}$ \\
\hline & Sit/Stand Test (repetitions) & None & Chronometer & $\mathrm{SLH}^{+}$ \\
\hline & Handgrip strength (Kgf) & None & Dynamometer Crow & $\mathrm{SLH}^{+}$ \\
\hline & Physical activity level (min/week) & Total; light; moderate; intense & Minnesota Questionnaire & $\mathrm{SLH}^{+}$ \\
\hline \multirow[t]{9}{*}{ Clinical } & Cognition & None & MMSE§ & $\mathrm{SLH}^{+}$ \\
\hline & Presence of cognitive loss & Yes/No & MMSE ${ }^{\S}$ & $\mathrm{SLH}^{+}$ \\
\hline & Body image satisfaction & Yes/No & Stunkard's Scale & $\mathrm{SLH}^{+}$ \\
\hline & Urinary incontinence & Yes/No & OAGAQ* & $\mathrm{SLH}^{+}$ \\
\hline & Report of falls in the last year & Yes/No & OAGAQ* & $\mathrm{SLH}^{+}$ \\
\hline & $\mathrm{N}^{0}$ of falls in the past year & $1 ; 2 ; \geq 3$ & $O A G A Q^{\star}$ & $\mathrm{SLH}^{+}$ \\
\hline & Fracture due to fall & Yes/No & $O A G A Q^{*}$ & $\mathrm{SLH}^{+}$ \\
\hline & Medication use & Yes/No & $O A G A Q^{\star}$ & $\mathrm{SLH}^{+}$ \\
\hline & $\mathrm{N}^{0}$ of medicines taken & None; $1-3 ; \geq 4$ & OAGAQ* & $\mathrm{SLH}^{+}$ \\
\hline
\end{tabular}

*OAGAQ: Older Adult Global Assessment Questionnaire; +SLH: São Lucas Hospital of the Pontifical Catholic University of Rio Grande do Sul; \$MMSE: Mini-Mental State Examination.

For the bivariate analyzes, the following tests were used: Student's $t$, Mann Whitney U and Pearson's Chisquare with continuity correction. For the estimation of the measure of effect, the Odds Ratio (OR) was used, with a $95 \%$ confidence interval (95\% CI).

As the "Body Image Satisfaction" outcome had a binary distribution, Logistic Regression was applied, where all variables with values of $\mathrm{p}<0.200$ in the bivariate analysis were selected for the multivariate analysis. The Backward (conditional) method was used from the saturated model. The association was evaluated using the likelihood-ratio test (2 LL or -2log) while the Nagelkerke and Hosmer-Lemeshow $\mathrm{R}^{2}$ estimators were employed to evaluate the quality of fit of final logistic regression model. The probability of gradual entry of the variables into the model was 0.05 and for removal was 0.10 . At the cut-off point, the significance was 0.50 for the maximum of 20 interactions. Levels below 0.01 were considered significant, based on the Bonferroni criterion.

\section{RESULTS}

Initially comprising 587 older adults; the final sample had 532 cases, after the exclusion of 55 cases (9.4\%) due to missing data for the variable "Satisfaction with body image". The sample (Table 2) contained predominantly individuals that were women $(64.8 \%)$, single (71.9\%), illiterate (92.8\%), and with a significantly higher mean age (69.4 \pm 7.5 years) than men (68.2 \pm 6.5 years).

Men were 2.5 times more likely to be satisfied with their body image than women (Table 2), where the majority of the latter were dissatisfied $(71.7 \%)$. The other variables shown in Table 2 had no significant association with BIS: age, age group, marital status, education and Physical Activity expressed as the four Minnesota Questionnaire scores.

None of the clinical characteristics of the sample were significantly associated with BIS: medicine use, polypharmacy, reported urinary incontinence, presence of cognitive decline, reported falls and fractures in the past year (Table 3). 
Table 2. Sociodemographic characteristics and physical activity of sample, according to body image satisfaction.

\begin{tabular}{|c|c|c|c|c|c|}
\hline \multirow[b]{2}{*}{ Variables } & & \multicolumn{2}{|c|}{ Body image satisfaction } & \multirow[b]{2}{*}{$\mathbf{p}^{\star}$} & \multirow{2}{*}{$\frac{\text { Crude }^{\mathrm{OR}^{+}}}{95 \% \mathrm{Cl}^{\S}}$} \\
\hline & & Yes $(n=165)$ & No $(n=367)$ & & \\
\hline \multirow[t]{2}{*}{ Sex" } & Male & $83(50.3)$ & $104(28.3)$ & $<0.001^{\star \star}$ & $2.560(1.750-3.744)$ \\
\hline & Female & $82(49.7)$ & $263(71.7)$ & 1.0 & \\
\hline Age (years) & Mean_SDๆ (Range) & $69.3 \pm 7.9(60.0-103.8)$ & $68.7 \pm 6.8(58.9-95)$ & $0.402^{++}$ & 1.011 (0.9866-1.037) \\
\hline \multirow[t]{3}{*}{ Age group" } & $60-69$ years & $103(62.4)$ & $235(64.0)$ & 0.840 ** & 1.0 \\
\hline & $70-79$ years & $47(28.5)$ & $104(28.3)$ & & $1.002(0.681-1.162)$ \\
\hline & $\geq 80$ years & $15(9.1)$ & $28(7.6)$ & & $1.056(0.841-1.155)$ \\
\hline \multirow[t]{2}{*}{ Marital status" } & Living with a partner & $70(42.4)$ & $135(36.8)$ & $0.216^{\star \star}$ & $1.266(0.871-1.842)$ \\
\hline & Not living with a partner & $95(57.6)$ & 232 (63.2) & & 1.0 \\
\hline \multirow[t]{2}{*}{ Education" } & Illiterate & $147(89.1)$ & $339(92.4)$ & $0.213^{\star *}$ & 1.0 \\
\hline & Low Education & $18(10.9)$ & $28(7.6)$ & & $0.675(0.362-1.258)$ \\
\hline \multicolumn{2}{|c|}{$\begin{array}{l}\text { Total Physical Activity (min/week) }{ }^{\S \S} \\
\text { Median (1 }{ }^{\text {st }-3^{\text {rd }}} \text { Quartile) }\end{array}$} & $2,519.0(1,500.0-4,917.0)$ & $3,420.0(1,831.0-4,341.0)$ & $0.067^{\|-\|}$ & $0.811(0.599-1.033)$ \\
\hline \multicolumn{2}{|c|}{$\begin{array}{l}\text { Light Physical Activity (min/week) })^{\S \S} \\
\left.\text { Median ( } 1^{\text {st_-3 }}{ }^{\text {rd }} \text { Quartile }\right)\end{array}$} & 1,866.0 (902.0-3,122.0) & $2,382.0(1,384.0-4,341.0)$ & $0.078^{\|-\|}$ & $0.855(0.602-1.016)$ \\
\hline \multicolumn{2}{|c|}{$\begin{array}{l}\text { Moderate Physical Activity (min/week) })^{\S \S} \\
\text { Median ( } 1^{\text {st }}-3^{\text {rd }} \text { Quartile) }\end{array}$} & 1,429.0 (598.0-2,721.0) & $1,541.0(530.0-3,409.0)$ & $0.081^{11-\|}$ & $0.892(0.577-1.098)$ \\
\hline \multicolumn{2}{|c|}{$\begin{array}{l}\text { Intense Physical Activity (min/week) } \\
\text { Median ( } 1^{\text {st }}-3^{\text {rd }} \text { Quartile) }\end{array}$} & $464.0(280.0-1,276.0)$ & $873.0(285.0-2,078.5)$ & $0.330^{\|-\|}$ & $0.694(0.388-1.106)$ \\
\hline
\end{tabular}

*Minimum level of significance for bivariate analysis; + Odds Ratio; §95\% confidence interval for OR; "Data expressed as n (\%); "Standard deviation; **Pearson's Chi-square; ++Student's $t$-test for independent groups; \$\$Physical activity measured with Minnesota Questionnaire; "--"Mann Whitney test.

Regarding functional characteristics (Table 3), greater lower limb muscle strength was significantly associated with BIS where those with higher scores on the Sit/Stand test and greater HGS were 1.15 and 1.06 times more likely to be satisfied, respectively. On the other hand, the time to walk $10 \mathrm{~m}$ was not significantly associated with BIS (Table 3).

The initial and final models (6 steps) of the Multivariate Binary Logistic Regression applied for the prediction of BIS are shown in Table 4. The initial model included the variables sex, polypharmacy, time to walk $10 \mathrm{~m}$, Sit/Stand test, HGS, total minutes per week engaged in light and moderate physical activity. It was decided to use the total minutes per week engaged in physical activity because this variable not only had the minimum level of compatible significance, but also a larger number of valid cases to be analyzed.

In the confounding matrix, the total of correct answers was $75.0 \%$, where the model correctly classified $92.5 \%$ of the cases for which satisfaction was negative (dissatisfaction with body image) and $28.6 \%$ of the cases that confirmed BIS.

Due to the loss of the predictive power of certain variables, the final model comprised three variables, whereby the individuals satisfied with their body image can be predicted by higher scores for the Sit/Stand test (OR: 1.12; $\mathrm{p}=0.013$ ); greater HGS (OR: 1.06, $\mathrm{p}=0.049$ ), less time engaged in physical activity (OR: 0.77; $\mathrm{p}<0.001)$.

\section{DISCUSSION}

Less time engaged in physical activity (Table 2), increased muscle strength of upper (HGS) and lower limbs (Sit/Stand) (Table 3) were the only characteristics considered predictors of BIS, among the many variables analyzed in this sample of underprivileged older adults.

We found few reports in the literature similar to the present article. There are scant articles on BIS in this age group while studies associating body image with physical function are even scarcer. There are exceptions, however, such as a study carried out in Spain with institutionalized older adults, which corroborates our findings regarding the relationship between functional tests and BIS. The authors reported a positive relationship between BIS and walking speed, where faster walkers had greater satisfaction with their body image and better perceived health. ${ }^{14}$

Another study also analyzing physical function was conducted by Reboussin et al., ${ }^{16}$ who found no relationship between exercise tests and body function. They 
Table 3. Clinical and functional characteristics of sample according to body image satisfaction.

\begin{tabular}{|c|c|c|c|c|c|}
\hline \multirow[b]{2}{*}{ Variables } & & \multicolumn{2}{|c|}{ Body image satisfaction } & \multirow{2}{*}{$\mathbf{p}^{*}$} & \multirow{2}{*}{$\begin{array}{c}\text { Crude } \mathrm{OR}^{+} \\
95 \% \mathrm{Cl}^{\S}\end{array}$} \\
\hline & & Yes $(n=165)$ & No $(n=367)$ & & \\
\hline \multirow[t]{2}{*}{ Medication" } & Yes & $140(88.6)$ & $324(90.5)$ & $0,510^{\S}$ & 1.0 \\
\hline & No & $18(11.4)$ & $34(9.5)$ & & $1.068(0.869-1.313)$ \\
\hline \multirow[t]{2}{*}{ Polypharmacy" } & Yes & $84(52.2)$ & $208(58.6)$ & $0.173^{\S}$ & 1.0 \\
\hline & No & $77(47.8)$ & $147(41.4)$ & & $1.142(1.021-1.278)$ \\
\hline \multirow[t]{2}{*}{ Urinary incontinence } & Yes & $51(31.5)$ & $120(33.3)$ & $0.677^{\S}$ & $0.943(0.618-1.367)$ \\
\hline & No & $111(68.5)$ & $240(66.7)$ & & 1.0 \\
\hline \multirow{2}{*}{$\begin{array}{l}\text { Presence of cognitive } \\
\text { impairment" }\end{array}$} & Yes & $43(27.6)$ & $109(30.8)$ & $0.463^{\S}$ & $0.855(0.563-1.298)$ \\
\hline & No & $113(72.4)$ & $245(69.2)$ & & 1.0 \\
\hline \multirow[t]{2}{*}{ Fall in past year" } & Yes & $53(32.3)$ & $115(31.4)$ & $0.838^{\S}$ & 1.0 \\
\hline & No & $111(67.7)$ & $251(68.6)$ & & $1.042(0.702-1.546)$ \\
\hline \multirow[t]{3}{*}{$\mathrm{N}^{0}$ of falls in past year" } & 1 & $25(47.2)$ & $46(41.1)$ & $0.515^{\S}$ & $0.793(0.369-1.702)$ \\
\hline & 2 & $16(30.2)$ & $31(27.7)$ & & $0.716(0.502-1.195)$ \\
\hline & $\geq 3$ & $12(22.6)$ & $35(31.3)$ & 1.0 & \\
\hline \multirow[t]{2}{*}{ Fracture after fall ${ }^{\|}$} & Yes & $12(22.6)$ & $31(27.0)$ & $0.551^{\S}$ & $0.793(0.369-1.702)$ \\
\hline & No & $41(77.4)$ & $84(73.0)$ & & 1.0 \\
\hline \multicolumn{2}{|l|}{$\begin{array}{l}\text { Time to walk } 10 \mathrm{~m} \text { (s) } \\
\text { Mean } \pm S D^{\uparrow} \text { (Range) }\end{array}$} & $6.3 \pm 1.7(3.0-13.0)$ & $6.8 \pm(3.0-20.0)$ & $0.104^{\star \star}$ & $0.850(0.761-1.250)$ \\
\hline \multicolumn{2}{|c|}{$\begin{array}{l}\text { Sit/Stand Test (number of repetitions/30s) } \\
\text { Mean } \pm \text { SD" (Range) }\end{array}$} & $9.7 \pm 3.4(1.0-23.0)$ & $8.4 \pm 2.9(1.0-18.0)$ & $0.009^{\star \star}$ & 1.147 (1.076-1.222) \\
\hline \multicolumn{2}{|l|}{$\begin{array}{l}\text { Handgrip Strength (Kgf) } \\
\text { Mean } \pm S D \text { " (Range) }\end{array}$} & $29.4 \pm 9.5(11.4-50.0)$ & $24.7 \pm 8.8(5.2-45.8)$ & $<0.001^{\star \star}$ & $1.055(1.033-1.078)$ \\
\hline
\end{tabular}

*Minimum level of significance for bivariate analysis; +0dds Ratio; ${ }^{995 \%}$ confidence interval for Odds Ratio; \$Pearson's Chi-square; "Data expressed as $n$ (\%); "Standard deviation; *^Student's $t$-test for independent groups.

Table 4. Multivariate Binary Logistic Regression Models for prediction of satisfaction with body image.

\begin{tabular}{|c|c|c|c|c|c|c|c|}
\hline \multirow{3}{*}{\multicolumn{2}{|c|}{ Independent variables }} & & & \multirow{4}{*}{$\frac{\text { Sig." }}{0.484}$} & \multirow{4}{*}{$\frac{\operatorname{Exp}(B)^{\uparrow}}{0.728}$} & \multicolumn{2}{|c|}{ djusted Odds Ratio } \\
\hline & & \multicolumn{2}{|c|}{ Regression coefficient } & & & \multicolumn{2}{|c|}{$95 \% \mathrm{Cl}^{*}$} \\
\hline & & $\mathbf{B}_{\text {crude }}{ }^{+}$ & $\mathbf{S E}^{\S}$ & & & Lower & Upper \\
\hline \multirow[t]{7}{*}{ Initial model } & Male & -0.317 & 0.453 & & & 0.300 & 1.769 \\
\hline & Time to walk $10 \mathrm{~m}$ & 0.060 & 0.094 & 0.525 & 1.061 & 0.883 & 1.275 \\
\hline & Sit/Stand & 0.124 & 0.053 & 0.018 & 1.132 & 1.021 & 1.255 \\
\hline & Handgrip strength & 0.073 & 0.026 & 0.005 & 1.076 & 1.022 & 1.132 \\
\hline & Total physical activity ${ }^{\star \star}$ & -0.084 & 0.054 & 0.050 & 0.851 & 0.693 & 1.074 \\
\hline & No polypharmacy & -0.493 & 0.404 & 0.223 & 0.611 & 0.277 & 1.349 \\
\hline & No history of falls & 0.009 & 0.314 & 0.977 & 1.009 & 0.545 & 1.868 \\
\hline \multirow[t]{3}{*}{ Final model } & Sit/Stand & 0.116 & 0.047 & 0.013 & 1.123 & 1.025 & 1.231 \\
\hline & Handgrip strength & 0.060 & 0.016 & 0.000 & 1.062 & 1.028 & 1.096 \\
\hline & Total physical activity ${ }^{\star \star}$ & -0.844 & 0.022 & 0.004 & 0.766 & 0.522 & 0.908 \\
\hline
\end{tabular}

${ }^{\star}$ Odds Ratio 95\% confidence Interval; + Crude regression coefficient; ${ }^{5}$ Standard error for regression coefficient; "Minimum level of significance for regression coefficient; " 0 dds ratio; ${ }^{\star *}$ Physical activity measured with Minnesota Questionnaire in minutes per week. Initial Model - Note: Nagelkerke R² 0.324; Test of Hosmer-Lemeshow (Chi-squared=32.447; $\mathrm{p}=0.336$ ); Cox \& Snell: 0.362; Overall score ratio - confounding matrix: 74.7\%. Final Model - Note: Nagelkerke $\mathrm{R}^{2}$ 0.388; Test of Hosmer-Lemeshow (Chi-squared=46.503; $\mathrm{p}=0.580$ ); Cox \& Snell: 0.362; 0verall score ratio - confounding matrix: $84.2 \%$. 
observed that perceived well-being was more related to body function than appearance, suggesting that, unlike younger populations, older adults place more importance on physical function. The authors concluded that there was a distinction between satisfaction with function and satisfaction with appearance among the older adults. $^{16}$

In contrast with our findings, Umstattd et al. ${ }^{28}$ reported that, among older adults, being satisfied with body image was related to higher levels of moderate to intense physical activity. While their sample comprised mostly people with medium-to-high educational level $(91.74 \%),{ }^{28}$ our study participants were mostly low educated or illiterate. This may explain the conflicting findings, given that low educated older adults tend to be less active and more satisfied with their body weight than individuals who are active and/or partially active with medium or high education, ${ }^{29}$ and also often lack a clear notion of the risk that excess weight can pose. ${ }^{30}$

Moreover, Sarabia ${ }^{14}$ used the Stunkard's Scale in his sample, also composed mainly of older adults with low education. However, it is not possible to compare their sample's levels of physical activity against the present sample because we measured and classified the engagement in physical activity using an instrument, while Sarabia $^{14}$ only asked their subjects whether or not they engaged in physical activity (active $\mathrm{x}$ inactive). Considering that their subjects were all institutionalized, their level of physical activity was very likely closer to that of the participants of the present study who reported engaging less time in physical activity and declared being satisfied with their body image.

In older adults, the relationship between BIS and longer time engaged in light physical activity might be due to the fact that they place more importance on body function than body appearence. ${ }^{31}$ Therefore, if satisfied with their physical function, they do not see the need to perform more intense physical activity.

As in the general population, there was a predominance of females in the present study sample, where women also made up the majority of individuals dissatisfied with their body image (72.4\%). This finding is corroborated by most articles published on this subject, $4,6,10,12,16,28,31,32$ and there is evidence that this dissatisfaction with their body is something that accompanies women from a young to an old age, as pointed out by longitudinal studies. ${ }^{4,10,12}$ This lifelong dissatisfaction is likely a result of the pressure that society places upon women through the imposition of ideals regarding body and beauty, which prove unattainable for most women. ${ }^{33}$
Mellor et al. ${ }^{31}$ argued that one of the reasons men are more satisfied with their body image is that they are more realistic with their own body appearance.

In spite of body image dissatisfaction being a predominantly female characteristic, it is not a consensus in the literature, since there are studies that point to the opposite among older adults. ${ }^{11,34}$ Paxton and Phythian ${ }^{11}$ concluded that men are more affected by age in relation to their BIS and self-esteem, as they feel less attractive with aging. Baker and Gringart ${ }^{34}$ came to a similar conclusion in their study, after demonstrating that men's self-esteem diminishes greatly as they age.

In contrast with the present study results, another study also conducted in Brazil and using the Stunkard Scale, Menezes et al. ${ }^{35}$ found a larger proportion of older people satisfied with their body image: $51.3 \%$ of the women and $68 \%$ of the men. These findings contradict those of the vast majority of articles found in the literature, including the present study. ${ }^{9,14,28,36}$ The authors concluded that being an older man acts as a protective aspect regarding BIS. ${ }^{35}$

We found two main differences between the present study and that by Menezes et al., ${ }^{35}$ both involving Brazilian older adults and using the Stunkard Scale. While their study was based on the census distribution, which encompasses people from all socioeconomic and demographic strata, the present study sample was drawn from a low-income and poorly educated population that was dependent on public health care, which is offered in areas of greater social vulnerability. ${ }^{19}$ Another explanation for this discrepancy between these two studies of Brazilian older adults may be the climatic, geographical and cultural differences between the two regions where they were carried out, having been conducted in the Northeast in the case of Menezes and in the South for the present study. As observed among younger Brazilians by Alvarenga et al., ${ }^{37}$ those in the southern region regarded themselves as burlier compared with young people from other regions of the country.

Other authors have reported that BIS in older adults is more related to functionality. ${ }^{11,15,16,28,38}$ However, these studies were based only on the participants' self-reports, without aspects of their functioning being measured, as was done in the present study. This methodological difference makes it difficult to compare the findings of the present study with those based only on the reports of the older adults surveyed, since it is known that they tend to overestimate their capacity, which may affect the final result of the studies that use self-report as a way of measuring aspects of functioning in this population group. ${ }^{39,40}$ 
Regardless of this possible methodological drawback in some of the studies, there are indications that functioning is a protective factor against body image dissatisfaction. ${ }^{9}$ Umstattd et al. ${ }^{28}$ demonstrated an association between high body function satisfaction and high levels of functional capacity, rather than with physical appearance. Alleva et al..$^{38}$ suggested that, as appearance becomes less important in mature women, other aspects such as functioning become more important. Paxton and Phytian ${ }^{11}$ argued that health and functioning are strong predictors of self-esteem in older adults, in both women and men. Thus, it seems, despite the fact that body image dissatisfaction affects older adults, its meaning is not the same as for young people, since their concern with their body is more related to functional than esthetic aspects. ${ }^{31,35}$ Moreover, dissatisfaction is often associated with chronic diseases, such as arthritis and cancer. ${ }^{9}$

For older adults with chronic diseases, this body image dissatisfaction is even more of an issue than the classic signs of aging, such as wrinkles, white hair or sagging skin. ${ }^{41}$ This is explained by the fact that loss of functional capacity and health negatively impacts physical appearance, promoting a greater degree of physical discomfort and reduced physical functioning. ${ }^{36}$ This concern of older adults with their body involves something much more complex. It has been suggested that this aspect be followed more closely by health professionals ${ }^{4,9,12,34}$ since this age group has the greatest risk of developing chronic diseases.

Therefore, it follows that one of the main contributions of the present study to the practice of health professionals in primary care was to demonstrate the feasibility of applying the Stunkard Scale at this level of healthcare, specifically with the population in their care. The instrument is low-cost, readily available, easy and quick to use, independent of educational level or full cognitive function, its application does not need specific training while its interpretation does not involve complicated calculations. Consequently, it should be easy to detect dissatisfied individuals and investigate other relevant aspects related to their health known to be associated with body image dissatisfaction, namely depression, anxiety, eating disorders, concerns about the effects of loss of autonomy or even the impact that the effects of aging can have on their social relationships. ${ }^{8}$ This is particularly relevant to elderly women with lower muscle strength, representing the majority of those dissatisfied with their body image, who may need to be referred for psychological support or programs tailored to help them accept the aging process and their body image.

The present study has several limitations related to its cross-sectional design, with only one measurement point, precluding the establishment of the direction of the causal relationship between BIS and predictive factors found, since this association can also be bidirectional. In spite of its limitations, it is pertinent to emphasize the representativeness of the sample investigated, which was sufficiently large for a prevalence study and selected in a random and proportional manner from all of the city's health districts, a factor which may have reduced the bias of selection. It is also noteworthy that the determination of the levels of physical activity and the functional tests were applied by trained professionals in the same place and setting for the entire sample, reducing the chances of errors derived from self-reports by the elders, their caregivers or family members..$^{39,40}$

Therefore, it can be concluded that the prevalence of BIS was low and associated with greater muscle strength and less time engaged in physical activity. Furthermore, as seen in younger populations, men are more satisfied than women with their body image in the elderly population.

Author contributions. All authors contributed significantly to, and approved, the content of this manuscript.

Grant support. This research received financial support from the Foundation for Research Support of the Brazilian State of Rio Grande do Sul (Fundação de Amparo à Pesquisa do Rio Grande do Sul - FAPERGS): proclamation 02/2009 PPSUS, processes $\mathrm{n}^{\circ}$ 09/0075-7 and 09/0055-0.

Acknowledgments. We would like to thank the participants and their families for their generosity and commitment, as well as the primary care unit teams.

\section{REFERENCES}

1. Ledoux M, Mongeau L, Rivard M. Poids et image corporelle. Enquête sociale et de santé auprès des enfants et adolescents québécois 1999 Québec: Institut de la statistique du Québec; 2002. p. 311-334. Cited by Roy M, Payette $\mathrm{H}$. The body image construct about Western seniors: A systematic review of a literature. Arch Gerontol Geriatr 2012;55 (3):505-21.
2. Tiggemann M, McCourt A. Body appreciation in adult women: Relationships with age and body satisfaction. Body Image 2013;10(4):624-27.

3. Campbell A, Hausenblas HA. Effects of exercise Interventions on Body image. J Health Psychol 2009;14(6):780-93.

4. Chisuwa N, O'Dea JA. Body image and eating disorders amongst Japanese adolescents. A review of the literature. Appetite 2010;54:5-15. 
5. Tiggemann $\mathrm{M}$, Williamson $\mathrm{S}$. The effect of exercise on body satisfaction and self-esteem as function of gender and age. Sex Roles 2000;43 (1-2):119-27.

6. Ridolfi DR, Crowther JH. The link between women's body image disturbances and body focused cancer screening behaviors: a critical review of the literature and a new integrated model for women. Body Image 2013;10:149-62

7. King TK, Matacin M, White KS, Marcus $\mathrm{BH}$. A prospective of body image and smoking cessation in women. Body Image 2005;2:19-28.

8. Wilson RE, Latner JD, Hayashi K. More than just body weight: The role of body in psychological and physical functioning. Body Image 2013;10:644-7.

9. Roy $\mathrm{M}$, Payette $\mathrm{H}$. The body image construct about Western seniors: A systematic review of a literature. Arch Gerontol Geriatr 2012;55(3): 505-21.

10. Öberg P, Tornstam L. Body image among men and women of different ages. Aging Soc 1999;19(5):629-44.

11. Paxton SJ, Phythian K. Body image, self-esteem, and health status in middle and later adulthood. Aust Psychol 1999;34(2):116-21.

12. Peat CM, Peyerl NL, Muehlenkamp JJ. Body image and eating disorders in older adults: a review. J Gen Psychol 2008;135(4):343-58.

13. Pereira EF, Teixeira CS, Borgatto AF, Daronco LSE. Relação entre diferentes indicadores antropométricos e a percepção da imagem corporal em idosas ativas. Rev Psiq Clín 2009;36(2):54-9.

14. Sarabia CM. La imagen corporal em los ancianos: estudio descriptivo. Gerokomos 2012;23(1):15-8

15. Latorre Román PA, García-Pinillos F, Huertas Herrador JA, Cózar Barba M, Muñoz Jiménez M. Relationship between sex, body composition, gait speed and body satisfaction in elderly people. Nutr Hosp 2014;30 (4):851-7.

16. Reboussin BA, Rejeski WJ, Martin KA, Kelley Callahan, Dunn Al, King AC, Sallis JF. Correlates of satisfaction with body function and body appearance in middle and older aged adults: the activity couseling trial (ACT). Psychol Health 2000;15:239-54

17. Rae MJ, Butler RN, Campisi J, de Grey AD, Finch CE, Gough M, et al. The demographic and biomedical case for late life interventions in aging. Sci Transl Med 2010;2 (40):40cm21. doi: 10.1126/ scitransImed.3000822.

18. World Health Organization. Luxembourg: WHO Library Cataloguingin-Publication Data; 2015. World report on ageing and health (online). Available at: http://apps.who.int/iris/bitstream/10665/186463/1/9789 240694811_eng.pdf. Accessed: March 8, 2018.

19. Brazilian Health Ministry [Ministério da Saúde]. The Implementation of the Family Health Unit [A Implantação da Unidade de Saúde da Família]. Brasília: Ministério da Saúde; 2000. Available from: http://bvsms.saude. gov.br/bvs/publicacoes/implantacao_unidade_saude_familia_cab1.pdf. Accessed: March 8, 2018

20. Gomes I, Nogueira EL, Engroff P, Ely LS, CHA, Geraldo Attilio De Carli, de Lima Resende T. The Multidimensional Study of the Elderly in the Family Health Strategy in Porto Alegre, Brazil (EMI- SUS). PAJAR 2013;1 (1):20-4.

21. Scagliusi FB1, Alvarenga M, Polacow VO, Cordás TA, de Oliveira Queiroz GK, Coelho D, et al. Concurrent and discriminate validity of the Stunkard's figure rating scale adapted into Portuguese. Appetite 2006; $47: 77-82$.

22. Jones CJ, Rikli RE, Beam WC. A 30-s chair-stand test as a measure of lower body strength in community-residing older adults. Res Q Exerc Sport 1999;70 (2):113-9.

23. Roberts HC, Denison HJ, Martin HJ, Patel HP, Syddall H, Cooper C, Sayer AA. A review of the measurement of grip strength in clinical and epidemiological studies: towards a standardized approach. Age Ageing 2011;40:423-9.

24. Graham JE, Ostir GV, Fisher SR, Ottenbacher KJ. Assessing walking speed in clinical research: a systematic review. J Eval Clin Pract 2008;14 (4):552-62.

25. Sardinha A, Levitan MN, Lopes FL, Perna G, Esquive G, Griez EJ, Nardi AE. Tradução e adaptação transcultural do Questionário de Atividade Física Habitual. Rev Psiquiatr Clín 2010;37(1):16-22.

26. Taylor HL, Jacobs DR Jr, Schucker B, Knudsen J, Leon AS, Debacker G. A questionnaire for the assessment of leisure time physical activities. J Chronic Dis 1978;31:741-55

27. Bertolucci PHF, Brucki SMD, Campacci SR, Juliano Y. O Mini-Exame do Estado Mental em uma população geral: impacto da escolaridade. Arq Neuropsiquiatr 1994:52:1-7.

28. Umstattd MR, Wilcox S, Dowda M. Predictors of change in satisfaction with body appearance and body function in mid-life and older adults: Active for life. Ann Behav Med 2010;41:342-52.

29. von Lengerke T, Mielck A; KORA Study Group. Body weight dissatisfaction by socioeconomic status among obese, preobese and normal weight women and men: results of the cross-sectional KORA Augsburg S4 population survey. BMC Public Health 2012;12:342.

30. Monteagudo C, Dijkstra SC, Visser M. Self- Perception of Body Weight Status in Older Dutch Adults. J Nutr Health Aging 2015;19 (6):612-618.

31. Mellor D, Tyszkiewicz MT, McCabe MP, Ricciardelli LA. Body image and self-esteem across age and gender: A short-term longitudinal study. Sex Roles 2010;63 (9):672-81.

32. Feingold A, Mazella R. Gender differences in body image are increasing. Psychol Science 1998;9 (3):190-5.

33. Holland G, Tiggemann M. A systematic review of the impact of the use of social networking sites on body image and disordered eating outcomes. Body Image. 2016;17:100-10.

34. Baker L, Gringart E. Body image and self-esteem in older adulthood. Aging Society 2009;29:977-95

35. Menezes TN, Brito KQD, Oliveira ECT, Pedraza DF. Body image perception and associated factors among elderly residents in a city in northeas Brazil: a population based study. Cien Saude Colet 2014;19(8):3451-60.

36. Rakhkovskaya LM, Hollan JM. Body dissatisfaction in older adults with a disabling health condition. J Health Psychol 2015;22(2):248-54.

37. Alvarenga MS, Philippi ST, Lourenço BH, de Morais Sato P, Scagliusi FB. Insatisfação com imagem corporal em universitárias brasileiras. J Bras Psiquiatr 2010;59(1):44-51.

38. Alleva JM, Martijn C, Jansen A, et al. Body language affecting body satisfaction by describing the body in functionality terms. Psychol Women Q 2014;38(2):181-97

39. Rubenstein LZ, Schairer C, Wieland GD, Kane R. Systematic biases in functional status assessment of elderly adults: effects of different data sources. J Gerontol 1984;39(6):686-91.

40. Feuering R, Vered E, Kushnir T, Jette AM, Melzer I. Differences between self-reported and observed physical functioning in independent older adults. Disabil Rehabil 2014;36(17):1395-401.

41. Clarke LH, Griffin M. Failling bodies: body image and multiple chronic conditions on later life. Qual Health Res 2008;18(8):1084-95. 